\title{
APPLICATION OF THE SAR INTERFEROMETRIC METHODS TO IDENTIFY THE MOBILITY OF THE AREA ABOVE THE SALT DIAPIR IN INOWROCŁAW AND THE REGIONAL SALT STRUCTURES IN CENTRAL POLAND
}

\author{
Zastosowanie satelitarnej interferometrii radarowej \\ do identyfikacji mobilności terenu nad wysadem solnym w Inowroclawu \\ oraz form solnych centralnej Polski
}

\author{
Anna PIĄTKOWSKA ${ }^{1}$, Maria SURAŁA ${ }^{1}$, Zbigniew PERSKI ${ }^{2}$ \\ \& Marek GRANICZNY ${ }^{1}$ \\ ${ }^{1}$ Państwowy Instytut Geologiczny-Państwowy Instytut Badawczy; \\ ul. Rakowiecka 4,00-975 Warszawa; e-mail: Anna.Piatkowska@pig.gov.pl, \\ Marek.Graniczny@pgi.gov.pl,Maria.Surala@pgi.gov.pl \\ ${ }^{2}$ Państwowy Instytut Geologiczny-Państwowy Instytut Badawczy, Oddział Karpacki, \\ ul.Skrzatów1,31-560 Kraków; e-mail: Zbigniew.Perski@pgi.gov.pl
}

\begin{abstract}
Remote sensing interpretation presents the linear structural elements correspond to the tectonic-structural pattern and suggest a block-type character of the pre-Permian basement. They may also indicate the existence of active movements of salt bodies and point at tectonic zones being active during almost recent past. The research on terrain mobility in the Inowrocław salt dome area and regional salt structures was conducted with the use of SAR interferometry techniques: PSI and InSAR. All archival scenes (both descending and ascending) available from satellites ERS-1/2 and ENVISAT were used in order to determine the nature of displacement during the last 15 years. To identify the mobility of the pilot study, locally and regionally, the results from SAR interferometry techniques were analysed together with all types of collected data: tectonics, geophysical, geological, geodetic, and structural data. That gave indications about the uplift and subsidence in the salt dome area, as well as information about the types and causes (natural and induced) of mass movements.
\end{abstract}

Key words: terrain deformation, salt domes, salt structures, SAR interferometry, and persistent scatterers

Treść: W ujęciu regionalnym tektonika blokowa w podłożu kompleksu permskiego była jednym z ważniejszych czynników inicjujących i warunkujących dźwiganie się antyklin solnych ku górze. W wypadku wysadu solnego Inowrocławia występował naturalny proces dźwigania kopuły wysadu o różnym stopniu nasilenia, a jego skutkiem jest powolna aktywność stref tektonicznych. Przybliżone wartości przemieszczeń terenu lokalnie w rejonie wysadu i regionalnie w rejonie struktur solnych zostały określone na podstawie wyników badań interferometrii satelitarnej SAR metodami PSInSAR i DInSAR. Do wyznaczenia wartości przemieszczeń powierzchni terenu w ostatnich 15 latach zostały wykorzystane wszystkie dostępne sceny archiwalne (zarówno descending, jak i ascending) satelitów ERS-1/2 oraz ENVISAT. W celu wyznaczenia stref aktywnych tektonicznie wyniki interferometrii radarowej zostały zanalizowane przy użyciu wszystkich zgromadzonych typów danych: tektonicznych, teledetekcyjnych, geofizycznych, geologicznych, geodezyjnych oraz danych strukturalnych. Pozwoliło to na scharakteryzowanie procesu podnoszenia i osiadania terenu w wymiarze lokalnym oraz regionalnym oraz wykazanie wyraźnych związków z naturalnym procesem halotektoniki.

Słowa kluczowe: badanie ruchów powierzchni terenu, wysady solne, struktury solne, interferometria satelitarna, PSInSAR, DInSAR 


\section{INTRODUCTION}

The purpose of this study is to demonstrate realistic possibilities of using the remote sensing methods, based on interferometric analysis, for the determination of ground surface movements in the areas of salt structures. Our studies are supported by a detailed spatial analysis of geological and structural data, lithology and other important conditions not only of natural character.

The geological structure of the Inowrocław salt diapir (Fig. 1) is one of many salt formations which appear in Central Poland (the Kujawy Region) where, according to previous studies, the salt anticlines are the oldest and have the best conditions to form (Dadlez \& Marek 1974, Dadlez 1980, Hus et al. 1996, Marek \& Pajchlowa 1997, Dadlez et al. 2000, Bujakowski 2003).

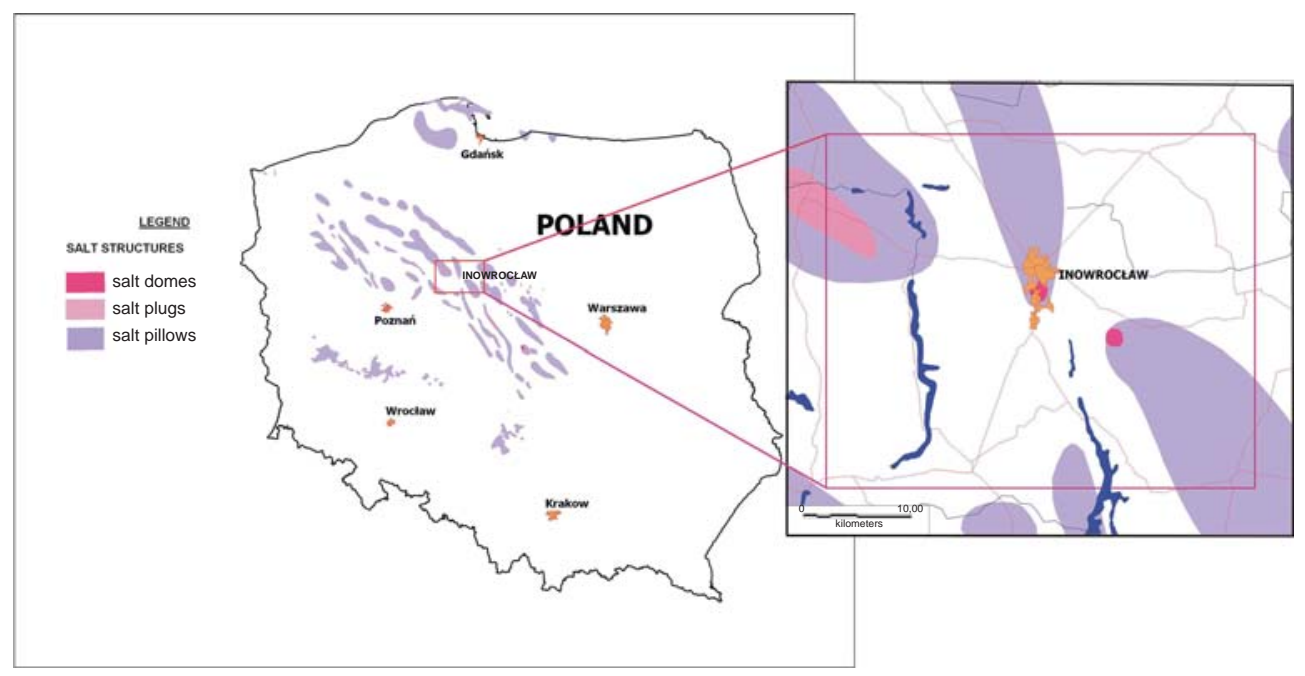

Fig. 1. Location of study area

Fig. 1. Lokalizacja obszaru badań

The Inowrocław salt dome is located directly under the Inowrocław town. Existence of this highly urbanised area that preserves interferometric coherence over the time creates an exceptional possibility to apply the SAR interferometry method to obtain highly precision. (Graniczny 1989, Perski et al. 2008, Graniczny et al. 2011, Piątkowska et al. 2011). The greatest advantages of SAR interferometry are the ability of large area coverage, and the high spatial data density of obtained measurements. It helps the data interpretation and further interpolation of the area of the Inowrocław town and its surroundings. 


\section{OBJECT OF STUDY}

The Inowrocław diapir was subjected to underground salt exploitation. Therefore, take into account the causes of its ground mobility in the context of the rock mass stress pattern associated with salt mining and the natural diapir uplift.

On the regional scale, the block tectonics of the Permian complex was one of the most important factors, which initiated and conditioned the uplift of salt anticlines. In the Inowrocław case, the natural dome uplifting process was continued with various rates, and it also resulted in small activities of the tectonic zones associated directly with the diapir. The tectonic zones continuing from the deep substratum to the surface layers. They were rejuvenated and they also contribute to the present-day ground mobility. Identification of these zones thanks to remote sensing analysis allows us to determine linear structural components that can indicate the existence of present-day tectonic zone activities in the Inowrocław area (Piątkowska 1989, 2003, 2007).

The mechanism of land surface mobility above the Inowrocław diapir can be a reference for regional analysis. The process is associated with current halo-tectonic activity.

However, we should assume that many other factors are responsible for terrain uplifting or subsidence. They include for example the following:

- lithology (e.g. the reaction of the gypsum cap with underground water, causing either the increase of the rock volume or and gypsum complex subsidence owing to loss of humidity);

- plastic properties of the salt complex (the "flow" phenomenon within the salt-bearing deposits);

- overburden weight causing the reduction of salt complex thickness under pressure;

- regional stress pattern around the salt diapir;

- rejuvenation of old tectonic structures, including especially halotectonics;

- changes in the ground-water table and interference of water relationships within old mine workings;

- changes in the local stress pattern in the mine working areas.

\section{INTERFEROMETRIC DATA}

To carry out research on the demonstration of the correlation between the geology of salt-bearing complexes (of diverse spatial range) and the land surface movements, we applied, archive data on the local geology and tectonics, and the SAR interferometry data that indicate land surface deformation.

The SAR interferometry method is based on satellite images such as ERS-1 and ERS-2. Deformation measurements consist in the calculation of the phase differences of the corresponding pixels of two SAR images acquired during subsequent satellite passes over the same area. In that method, based on two SAR images, we can obtain an interferogram presenting phase difference of the whole area covered by imaging. The deformation rates are calculated on the basis of single interferograms are not always accurate enough. The limiting factors that 
reduce the credibility of interferometric data are related to the phenomena, which occur in the troposphere (mainly diverse vapour content), errors in orbit calculation, and the changes occurring in the environment (e.g. vegetation). The InSAR method is proven well in case of land subsidence studies with large deformation rates, for example on coal or copper mining areas (e.g. Popiołek et al. 2002, Krawczyk et al. 2007, Perski 2010, Huanyin et al. 2011), or large tectonic deformations associated with extensive earthquakes (Perski \& Hanssen 2005).

To study small long-term displacements, we apply the interferometric methods based on the analysis of the so-called Persistent Scatterers (PS). Those methods use series of SAR images (usually more than 20), recorded over many years. The Persistent Scatterer Interferometry (PSI) assumes the use of the phenomenon of occurrence of the objects, which maintain coherence in the environment, thus ensuring reflected radar signal's phase and amplitude stability. Such objects (mainly building corners, roofs, pylons, or rock outcrops) constitute stable scatterers. In the PSI methods, we identify permanent scatterers (PS) on the series of SAR interferograms based on amplitude dispersion (Ferretti et al. 2001) or phase characteristics (Hooper 2008), followed by the analysis of only those stable points (Perski \& Mróz 2007). We should remember that the calculation of deformation rates in the PSI methods is conducted with the assumption of a specific deformation model (usually a linear one), and such measurements are relative. The measurements refer to one or more benchmarks identified on the area for which no deformation is assumed. The time reference consists in the assumption of one of the SAR scenes as reference scene (Kühn 2011, Graniczny \& Piątkowska 2005, Perski \& Mróz 2007, Refice et al. 2011).

The PSI method calculation result consists in the collection of points where each PS point has an assigned numerical value corresponding to the average deformation velocity (mm/year). In addition, for each of the points, we determine the deformation rate for each SAR scene, which allows us to construct a graph showing the deformation time series in the function of time (Fig. 2).

In case of the Inowrocław diapir, SAR data processing was carried out for the MELA Project (Morphotectonic of the European Lowland Areas) purposes by the SPINUA-CNR-ISSIA of the Polytechnics of Milan and Bari, Italy.

As the input data a series of SAR scenes acquired by the European satellites ERS-1/2 were used. The processing results were presented in the form of PS point dataset of average velocities ranging from $-5 \mathrm{~mm} /$ year to $+10 \mathrm{~mm} /$ year. For analytical purposes PS data were interpolated to create the displacement isoline maps. For comparison purposes, the mentioned SAR data were processed on the regional scale of $40 \mathrm{~km} / 40 \mathrm{~km}$, corresponding to the range of ca. $1 / 4$ of the ERS-1/2 satellite scenes. The data were processed by Z. Perski and T. Wojciechowski under the project called The Application of Satellite Radar Interferometry to the Identification of Ground Mobility over the Salt Diapir in the Inowroctaw Area No. 61-9202-1101-00-0, financed from the resources allocated to the activities conducted under PIG PIB's statutory operations. The respective analysis was applied to 31 ERS-1/2 SAR images of 1992-2007, with the use of PSI and SBAS methods (Lanari 2003), implemented in the StaMPS scientific software (Hooper 2008). In total, 31,773 PS points were obtained, with the average density of ca. $20 \mathrm{PS} / \mathrm{km}^{2}$. The relative deformation sizes range from $-10 \mathrm{~mm} / \mathrm{year}$ to $+10 \mathrm{~mm} /$ year, although the majority of the points $(90 \%$ each) indicated the deformations in the range from $-5 \mathrm{~mm} /$ year to $+5 \mathrm{~mm} /$ year. 

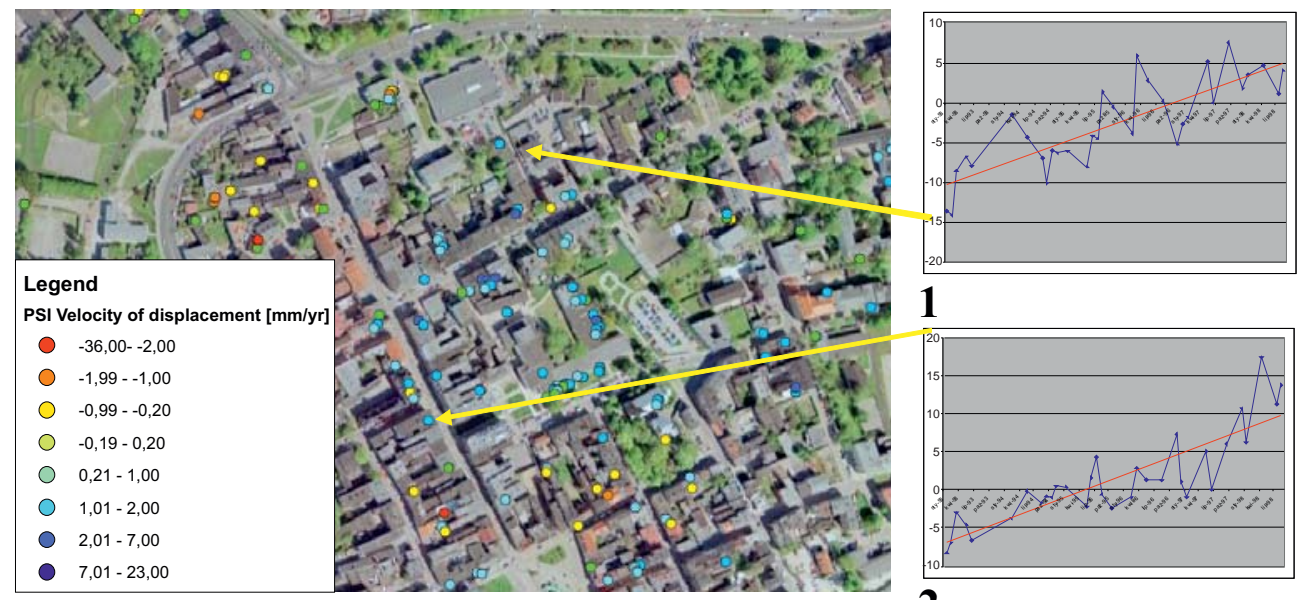

2

Fig. 2. Distribution of PS points in the Inowrocław Old Town area; uplifting trend with the average elevation of $3 \mathrm{~mm} / \mathrm{year}$

Fig. 2. Rozkład punktów PS w rejonie Starego Miasta; można przyjąć tendencję wynoszenia średnio $3 \mathrm{~mm} / \mathrm{rok}$

\section{ANALYSIS AND RESULTS}

The comparative studies of the geological structure of salt formations, in the context of the ground mobility observations, conducted on the basis of the ERS-1/2 SAR and ENVISAT observations, covered the period of 1996-1999. The analysis was conducted on the local scale (the Inowrocław diapir) and the regional scale on the fragments of salt anticlines of Inowrocław, Gopło, Barcin, and Góra.

We can infer from the presented interferometric data on the PS point value distribution in respect of the Inowrocław salt diapir that its central part is elevating (mostly in steps visible at the Time Series graph of figure 2). A slow uplifting movement is also indicated by the PS points situated in the following places: Old Town of Inowrocław, Rąbin and Nowe Osiedle housing estates, and the Składowa Street, with the values from 0 to $+8 \mathrm{~mm} / \mathrm{year}$ (Fig. 2). The slow diapir mass uplifting movement indicates a natural process of the phenomena subjected to the laws of halotectonics (Seni \& Jackson 1983, Hardy \& Langer 1984). The PSI research results (Figs 3,4) show the correspondence to the tectonic zones and suggest that the current activity is associated with continuous halotectonic processes.

However, the areas displaying a tendency to subside from $-2 \mathrm{~mm} / \mathrm{year}$ to $-1 \mathrm{~mm} / \mathrm{year}$ are probably associated with the gypsum-silt cap complex. The subsidence values ranging from $-4 \mathrm{~mm} / y e a r$ to $-1 \mathrm{~mm} /$ year appear in the areas of abandoned extraction shafts. The concentration of the PS points showing a tendency to subside occurs in the areas of the Piastowskie and Zacisze housing estates and the Zapadłe Str, which was confirmed by geodetic studies based on repeated precise levelling data (Szczerbowski 2002). 
We should emphasize that there is a clear relationship between the vertical movement rates and the changeability of lithological gypsum cap formation, including its thickness.

Attempts at the classification of the nature of movements in respect of their origin associated with both natural and induced phenomena led to the conclusion that both types of factors, natural and induced, are intermingled with various rates in the case of the Inowrocław diapir.

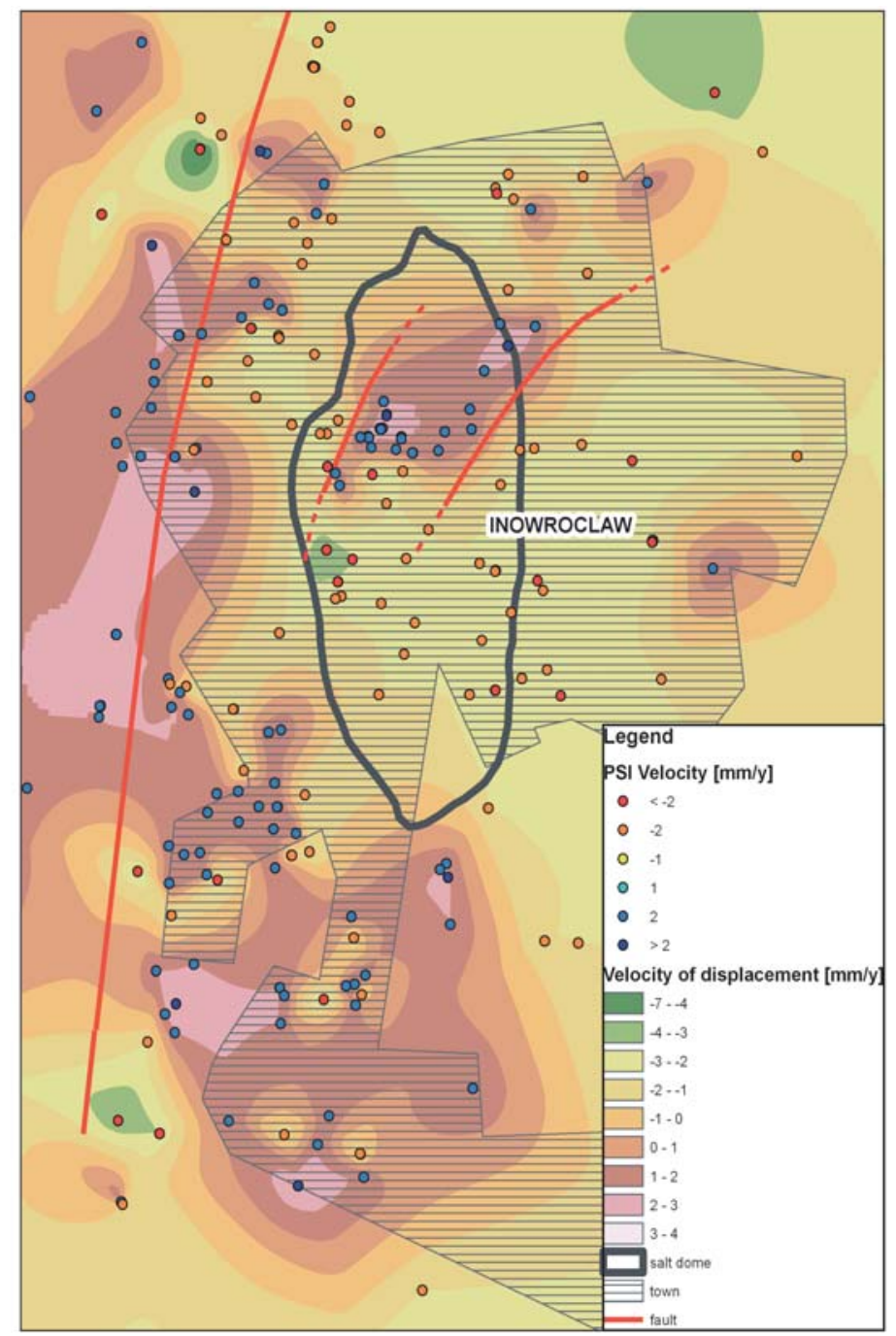

Fig. 3. Selected PS points on the background of a conceptual map of vertical movement trends

Fig. 3. Wybrane punkty PS na tle przybliżonej mapy trendów ruchów pionowych 


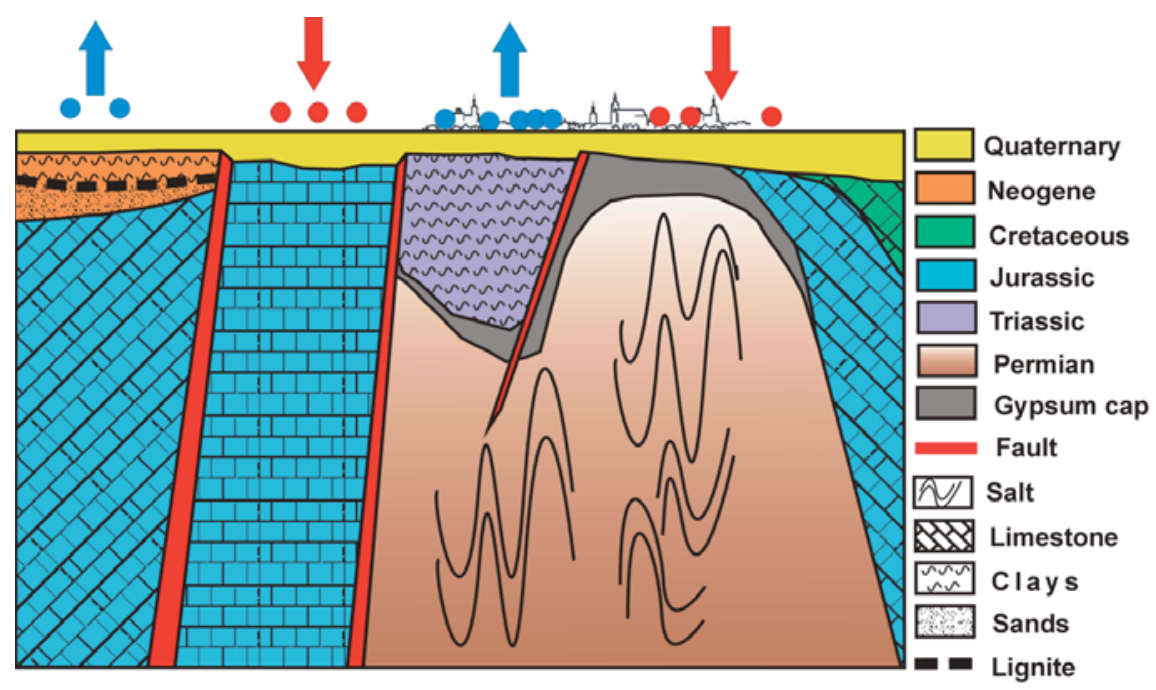

Fig. 4. Results of preliminary PSI studies show correlation with tectonic zones and suggest current salt dome activity (halotectonic activity)

Fig. 4. Wyniki wstępnych badań PSI wykazują związek ze strefami tektonicznymi oraz sugerują współczesną aktywności kopuły solnej (halotektonika)

Similar observations were made on a regional scale upon analysis of the following anticline areas: Barcin (west of Pakość), Góra, Gopło (south of Kruszwica), and Inowrocław. The observations and a detailed analysis of the Inowrocław diapir were used as the interpretation key and indicators for the evaluation of the interdependence of kinematic salt complex properties and their influence on the land surface dynamics in the area of the above-specified salt structures.

We also found a clear correlation between the morphology of the pre-Quaternary surface and the recent movements. The deformation velocities obtained from PSI compared with isoline map of Quarternary sediments base (compilation made by the data from: Listkowska 1991, Wrotek 1993, Jeziorski 1995, Brzeziński 2009) is presented on figure 5. An additional cross-section illustrates the identified interdependence: the positive values of PS points (uplifting) correspond to the morphological uplifts of the pre-Quaternary surface morphology.

The kinematic mechanism of Inowrocław salt structures is clearly translated into a regional salt structure. In figure 5, the salt formations and the respective locations on land surface corresponding to the pre-Quaternary surface uplifts show the tendency of uplifting. An example of the correspondence of PS velocities and the current uplifting phenomena is demonstrated by the anticline form of Barcin, situated west of Pakość. An additional element, which influences the land mobility, is intense and large-scale open-pit extraction of Jurassic limestone (on the surface and underground). That mining operation certainly influences the rock mass stress-relieving nature, within the studied structure, augmenting the elevation effect (Piątkowska 2003). 


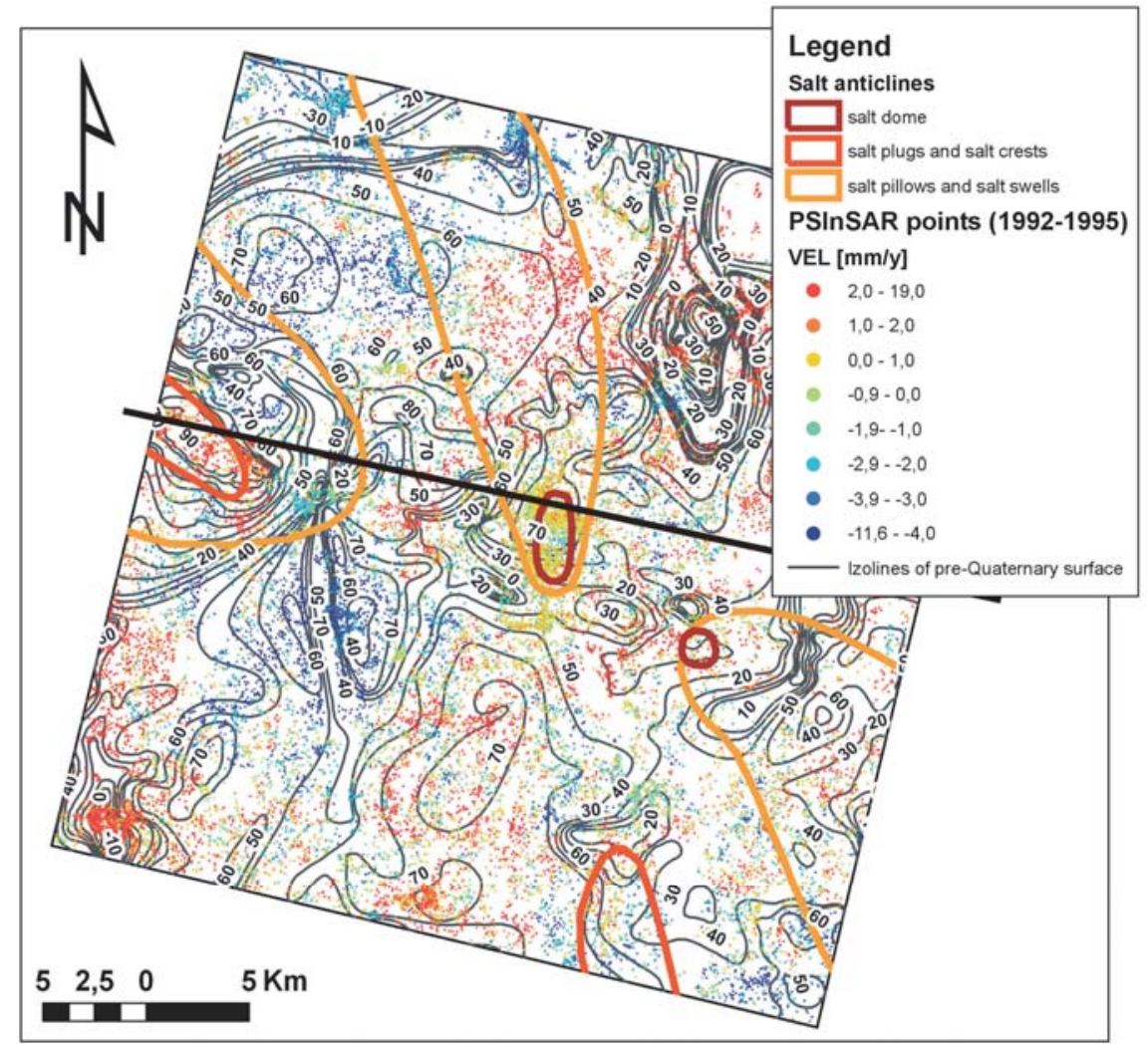

Fig. 5. Distribution of PS points against the isoline interpretation of Quaternary bed interpretation, with a general outline of salt formations

Fig. 5. Rozmieszczenie punktów PS na tle izoliniowej interpretacji podłoża czwartorzędu i z orientacyjnym zarysem form solnych

When analysing the occurrence of salt structures, we should mention compensation troughs, associated with the "outflow" of salt masses from the surroundings of the salt body being elevated to its centre. That phenomenon is also reflected in the land surface movement (Baraniecka 1980). Ground subsidence, documented by PS points, indicates exceptional matching with the compensation troughs situated in direct vicinity of the salt diapirs.

Interpolation maps (Fig. 6 - drawings A and B), show the interpretations of the pre-Quaternary surface morphology, in comparison to the interpolated values of the PS velocities. The figure is a graphic expression of the interdependences presented on the cross-section, where A is the pre-Quaternary morphological surface and B is the surface showing the interpolated PS point relocation rate values.

Such correlations could be more accurate when recognition of the pre-Quaternary surface better recognized by drilling and geophysical investigations. 

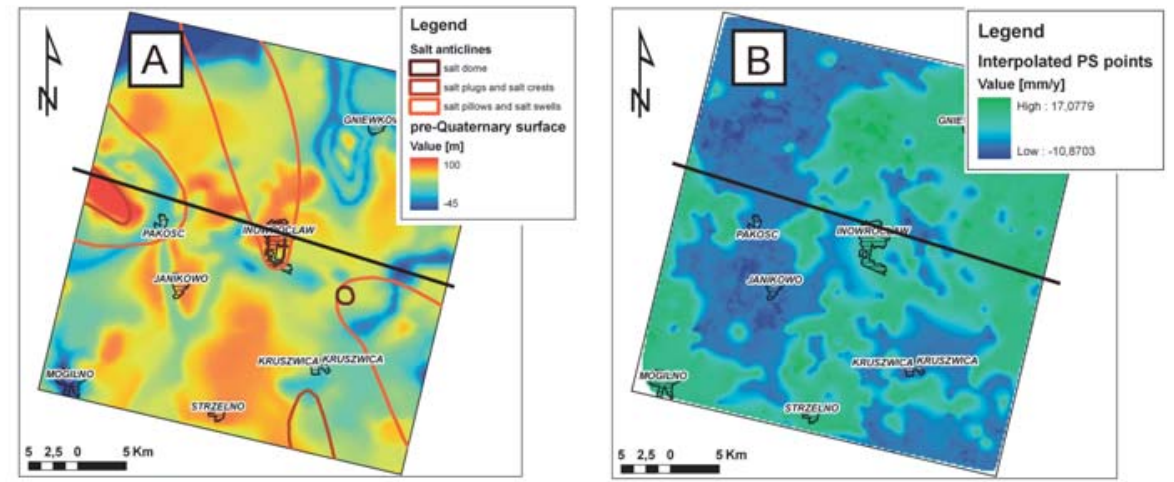

Cross-section

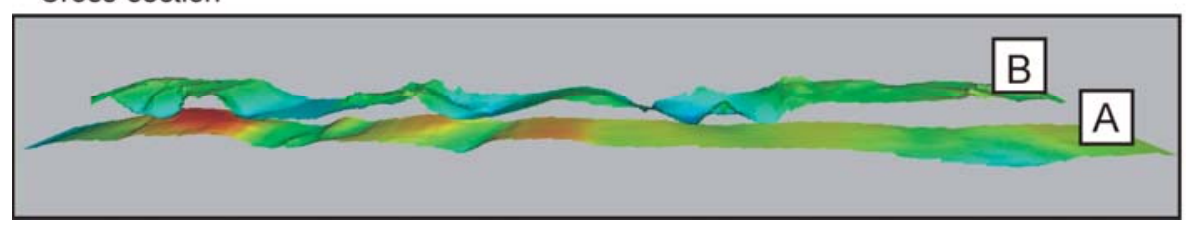

Fig. 6. Location of the cross-section which shows the relationship between pre-Quaternary morphological surface (A) and the surface representing interpolated PS velocity values (B)

Fig. 6. Lokalizacja przekroju, na którym przedstawiona została zależność pomiędzy ukształtowaniem powierzchni morfologicznej - podczwartorzędowej (A) a powierzchnią przedstawiającą zinterpolowane wartości prędkości ruchu PS (B)

\section{CONCLUSIONS}

The PSI ground displacement estimations obtained for the salt structures situated on the Polish Lowlands indicated a considerable potential of the remote sensing methods in the recognition of land surface movements. They can be used in both local (Inowrocław) and regional studies.

\section{Main interpretation results:}

1. Both, natural and induced ground movements were observed and confirmed at the local scale in the Inowrocław region.

2. General, the salt structures mobility in the regional scale was confirmed in the basis of the interferometric data. The rate of those movements is comparable to the geodetic measurements.

3. The PSIn SAR analysis, in the vicinity of salt domes has contributed to better recognition of per-Quatrenary surface morphology and estimation of the trends of contemporary small vertical movements.

Our regional studies indicated cohesion with the assumptions of the rock salt complex mechanics, and they can be used in planning of infrastructure projects associated with salt formations, e.g. for hydrocarbon storage and carbon dioxide capture and storage. 


\section{REFERENCES}

Baraniecka D.M., 1980. Geneza elementów wklęsłych powierzchni podłoża czwartorzędu na obszarze wału kujawskiego i niecki warszawskiej. Biuletyn Instytutu Geologicznego, 322, XXIV, 31-64.

Brzeziński M., 2009. Objaśnienia do szczegółowej mapy geologicznej Polski 1:50 000. Arkusz Inowrocław. CAG PIG PIB.

Bujakowski W. (red.) 2003. Termiczna charakterystyka górotworu w rejonie wysadów solnych. Wydawnictwo IGSMiE PAN, Kraków.

Dadlez R., 1980. Mapy tektoniczne cechsztyńsko-mezozoicznego kompleksu strukturalnego na Niżu Polskim w skali 1:500 000. Państwowy Instytut Geologiczny, Warszawa.

Dadlez R. \& Marek S., 1974. Budowa geologiczna Polski. Tektonika. Państwowy Instytut Geologiczny, Warszawa.

Dadlez R., Marek S. \& Pokorski J., 2000. Mapa geologiczna Polski bez utworów kenozoiku. W skali 1:1 000 000. Państwowy Instytut Geologiczny, Warszawa.

Ferretti A., Prati C. \& Rocca F. 2001. Permanent Scatterers in SAR Interferometry. IEEE Transactions on Geoscience and Remote Sensing, 39(1), 8-20.

Graniczny M., 1989. Fotolineamenty i ich znaczenie geologiczne. Klasyfikacja. In: Instrukcje i Metody Badań Geologicznych, 50, Instytut Geologiczny, Warszawa.

Graniczny M. \& Piątkowska A., 2005. Application of the remote sensing for seismic activity: the Upper Silesian Basin case. Proceedings of the conference "Mass movement hazard in various environments", October 20-21, Kraków, Poland.

Graniczny M., Bovenga F., Kowalski Z., Perski Z., Piątkowska A., Surała M., Uścinowicz S., Wasowski J. \& Zdanowski A., 2011. Problematyka wykorzystania interferometrii satelitarnej w badaniach geologicznych. Biuletyn Państwowego Instytutu Geologicznego 446, 53-64

Hardy H.R., Jr. \& Langer M., 1984. The Mechanical Behavior of Salt. Trans. Tech. Publications, Proceedings of the First Conference Sponsored by the Pennsylvania State University Rock Mechanics Laboratory.

Hooper A., 2008. A multi-temporal InSAR method incorporating both persistent scatterer and small baseline approaches. Geophysical Research Letters, 35, L16302.

Huanyin Y., Guang L., Perski Z. \& Huadong G., 2011. Satellite radar reveals land subsidence over coal mines. SPIE Newsroom, 3 pp.

Hus M., Jabłoński S., Jasiński Z. \& Lepiarz J., 1996. Działalność górnicza na złożu „Inowrocław" w latach 1871-1995. Inowrocław.

Jeziorski J., 1995. Objaśnienia do szczegółowej mapy geologicznej Polski 1:50 000. Arkusz Gniewkowo. PIG PIB.

Krawczyk A., Perski Z. \& Hanssen R., 2007. Application of ASAR interferometry for motorway deformation monitoring. ESA ENVISAT Symposium, Montreux, Switzerland, 23-27 April 2007.

Kühn F., 2011. Ground Motion Detection Using Persistent Scatter Interferometry - Berlin Case Study. Terrafirma User Workshop, Essen, March 22, 2011. 
Marek S. \& Pajchlowa M. 1997. Epikontynentalny perm i mezozoik w Polsce. Prace Państwowego Instytutu Geologicznego, CLIII, 6-9 and 410-415.

Lanari R., 2003. Small Baseline DIFSAR Techniques for Earth Surface Deformation Analysis. Third International Workshop on ERS SAR Interferometry, FRINGE03, Frascati, Italy, 1-5 December 2003.

Listkowska H., 1991. Objaśnienia do szczegółowej mapy geologicznej Polski 1:50 000. Arkusz Pakość. PIG PIB.

Perski Z. \& Mróz M., 2007. Zastosowanie metod interferometrii radarowej InSAR do badania naturalnych ruchów powierzchni terenu w Polsce. Projekt Geo-In-SAR, application of SAR interferometric (InSAR) methods for the study of natural earth surface displacements in Poland. Geo-In-SAR project. Archiwum Fotogrametrii, Kartografii i Teledetekcji, $17 \mathrm{~b}$.

Perski Z., Krawczyk A. \& Marinkovic P., 2008. Satelitarna interferometria radarowa (InSAR) wysokiej rozdzielczości z wykorzystaniem danych TerraSAR-X. Archiwum Fotogrametrii, Kartografii i Teledetekcji, 18a.

Perski Z. \& Hanssen R., 2005. The Interpretation of Bam Fault Kinematics Using Envisat SAR Interferometric Data. Proceeding of FRINGE05 workshop, Frascati Italy, 28 November - 2 December 2005, ESA SP-610 CD-ROM.

Perski Z., 2010. Kompleksowa analiza interferogramów. In: Zuberek W.M. \& Jochymczyk K. (red.), Geneza i charakterystyka zagrożenia sejsmicznego w Górnoślaskim Zagłębiu Węglowym, Wyd. UŚ, Katowice, 41-45.

Piątkowska A., 1989. Analizy fotogeologiczna rejonu Kujaw. Opr. Arch. CAG PIB PIB.

Piątkowska A., 2003. Cechsztyńsko-mezozoiczny kompleks strukturalny Kujaw w świetle cyfrowej analizy danych teledetekcyjnych. In: Instrukcje i Metody Badań Geologicznych, Instytut Geologiczny, Warszawa.

Piątkowska A., 2007. Remote Sensing methods for morphotectonic analysis of salt structures. Schriftenereihe der Deutschen Gesellschaft fur Geowissenchafen. Heft 53 GeoPomerania Szczecin. Geology cross-bordering the Western and Eastern European Platform. Joint Meeting DGG-PTG.

Piątkowska A., Graniczny M., Surała M. \& Perski Z., 2011. Application of SAR interferometric methods to identify the mobility of the area above salt diapir in Inowrocław City, Kujawy region (Poland) Abstract. FRINGE 2011 Workshop 19-23 September 2011, ESA-ESRIN, Frascati (Rome).

Popiołek E., Hejmanowski R., Krawczyk A. \& Perski Z., 2002. Application of Satellite Radar Interferometry to the examination of the areas of mining exploitation. Surface Mining Braunkohle \& Other Minerals, 54, 1, 74-82.

Refice A., Bovenga F., Pasquariello G., Denora D., Dolores Fidelibus M. \& Spilotro G., 2011. Bulging of the salt dome of Lesina Marina (Gargano, Southern Italy) revealed by DInSAR techniques. Geophysical Research Abstracts, 13.

Seni S.J. \& Jackson M.P.A., 1983. Evolution of salt structures, East Texas diapir province; Part 1, Sedimentary record of halokinesis. American Association of Petroleum Geologists Bulletin, 67, 8, 1219-1244. 
Szczerbowski Z., 2002. Badania geodezyjno-grawimetryczne efektów procesów geodynamicznych zachodzących w naruszonym eksploatacją górotworze solnym. WUG, 5, 27-28.

Wrotek K., 1993. Objaśnienia do szczegółowej mapy geologicznej Polski 1:50 000. Arkusz Złotniki Kujawskie. PIG PIB.

\section{Streszczenie}

Wysad solny Inowrocławia jest jedną z form geologicznych występujących na obszarze Kujaw i typową dla rejonu centralnej Polski (Fig. 1). W ujęciu regionalnym tektonika blokowa w podłożu kompleksu permskiego była jednym z ważniejszych czynników inicjujących i warunkujących dźwiganie się antyklin solnych ku górze. W wypadku Inowrocławia występował naturalny proces dźwigania kopuły wysadu o różnym stopniu nasilenia, a jego skutkiem jest powolna aktywność stref tektonicznych (Fig. 2). Propoagacja stref tektonicznych od głębszego podłoża ku warstwom przypowierzchniowym ulegała i ulega nadal odmłodzeniu. Przy identyfikacji tych stref pomocna była analiza teledetekcyjna, umożliwiająca wyznaczenie liniowych elementów strukturalnych, które mogą wskazywać na współczesną aktywność stref tektonicznych w rejonie Inowrocławia. (Fig. 3, 4)

Przypuszcza się, że mechanizm mobilności terenu nad wysadem solnym Inowrocławia związany jest ze współczesną aktywnością halotektoniczną, a za wypiętrzanie lub osiadanie terenu odpowiedzialnych jest wiele innych czynników. Są to między innymi: litologia (np. reakcja czapy gipsowej z różnymi poziomami wód, powodując zwiększenie objętości skały lub przez utratę wilgoci - osiadanie kompleksu gipsowego); tektonika (uskoki, tektonika wysadu solnego); wpływ eksploatacji górniczej; zmiany poziomu wód gruntowych.

Przybliżone wartości przemieszczeń terenu w rejonie wysadu solnego i w rejonie struktur solnych określają wyniki badań interferometrii satelitarnej SAR metodami PSInSAR i DInSAR. Do wyznaczenia wartości przemieszczeń powierzchni terenu w ostatnich 15 latach zostały wykorzystane wszystkie dostępne sceny archiwalne (zarówno descending, jak i ascending) satelitów ERS-1/2 oraz ENVISAT (Fig. 5).

W celu wyznaczenia stref aktywnych tektonicznie została przeprowadzona szczegółowa analiza geologiczno-strukturalna. Zakres prac obejmował analizę danych archiwalnych kartograficznych odnoszących się do struktur geologicznych i obszarów kopalń solnych. Została stworzona baza danych GIS zawierająca dane tektoniczne, teledetekcyjne, geofizyczne, geologiczne, geodezyjne oraz dane strukturalne.

Pozwoliło to na scharakteryzowanie procesu podnoszenia i osiadania terenu w wymiarze lokalnym oraz regionalnym oraz wykazanie wyraźnych związków z naturalnym prcesem halotektoniki (Fig. 6). Zaprezentowane wyniki badań pokazują wagę i potencjał wykorzystania metody PS oraz technik satelitarnej interferometrii radarowej do badania ruchów masowych dla terenu nad loklanymi strukturami solnymi oraz w wymiarze regionalnym dla struktur solnych w rejonie Kujaw (centralna Polska). 